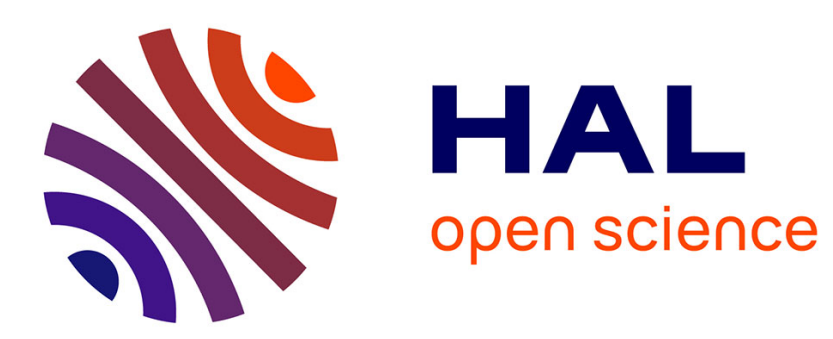

\title{
James Buchanan: Clubs and Alternative Welfare Economics
}

\author{
Alain Marciano
}

\section{To cite this version:}

Alain Marciano. James Buchanan: Clubs and Alternative Welfare Economics. Journal of Economic Perspectives, 2021, 35, pp.243 - 256. 10.1257/jep.35.3.243 . hal-03326422

\section{HAL Id: hal-03326422 \\ https://hal.umontpellier.fr/hal-03326422}

Submitted on 26 Aug 2021

HAL is a multi-disciplinary open access archive for the deposit and dissemination of scientific research documents, whether they are published or not. The documents may come from teaching and research institutions in France or abroad, or from public or private research centers.
L'archive ouverte pluridisciplinaire HAL, est destinée au dépôt et à la diffusion de documents scientifiques de niveau recherche, publiés ou non, émanant des établissements d'enseignement et de recherche français ou étrangers, des laboratoires publics ou privés. 


\title{
Retrospectives James Buchanan: Clubs and Alternative Welfare Economics
}

\author{
Alain Marciano
}

This feature addresses the history of economic terms and ideas. The hope is to deepen the workaday dialogue of economists, while perhaps also casting new light on ongoing questions. If you have suggestions for future topics or authors, please contact either Beatrice Cherrier, CNRS E CREST, ENSAE-Ecole Polytechnique (beatrice.cherrier@gmail.com) or Joseph Persky,University of Illinois at Chicago (jpersky@uic.edu).

\section{Introduction}

Club goods are characterized by non-rivalry in consumption, like pure public goods. Unlike pure public goods, however, club goods allow excludability in supply. In the case of a club good, a group of individuals both share the costs of provision of the good and limit its access, so that consuming the club good benefits only those who have paid a fee or a toll and are thus members of the club. This is the case of health or sport clubs, country clubs, as well as local public goods-such as swimming pools, museums, or libraries-but can also apply to groups of people using highways, the education system, hospitals, and the services of a police department or fire protection department.

James Buchanan (1965a) is considered the first to introduce this category of goods in economics. Buchanan's seminal article, "An Economic Theory of Club" (1965a), and its legacy have been widely discussed (in particular, see Sandler and

- Alain Marciano is University Professor of Economics, University of Montpellier, Montpellier, France. His email address is alain.marciano@umontpellier.fr.

For supplementary materials such as appendices, datasets, and author disclosure statements, see the article page at https://doi.org/10.1257/jep.35.3.243. 
Tschirhart 1980, 1997; Sandler 2013). However, the genesis of the idea of club goods has rarely been assessed from Buchanan's own perspective and work. This is what we do here, drawing on published and unpublished work and correspondence from the James M. Buchanan Papers archived at George Mason University..$^{\text {II }}$ This allows us to show the connection between Buchanan's work on the pricing of public goods and his criticism of Samuelson's welfare economics. Indeed, Buchanan invented the concept of club goods to support an alternative form of welfare economics, which could dispense with the use of a social welfare function. Clubs in the sense of Buchanan are thus foreign and incompatible with the traditional Samuelson-style public economics in which they are often used.2

Buchanan was convinced that social welfare functions-as used in Paul Samuelson's work that Buchanan targeted-were an arbitrary and unnecessary means to determine the individual contributions to the provision of a public good and to guarantee the desirability of an allocation of resources. Arbitrary, because the effect of social welfare function is to impose taxes independently from individual preferences and not needed because they ignore that individuals are willing to pay for the public goods they consume or, for that matter, the external effects they produce. Instead of using a social welfare function, Buchanan argued, individuals should pay a price based on their willingness to pay for public goods or external effects. Clubs were the institutional mechanism that would make the implementation of individualized prices for public goods or external effects possible.

This essay focuses on the development of Buchanan's views about clubs. We start with his beliefs about the pricing of public goods and the scope of welfare economics, and then proceed by explaining why and when clubs exist. We conclude with a discussion of the pricing mechanism Buchanan suggested for use in clubs.

\section{Buchanan (and Wicksell) versus Samuelson on Welfare Economics of Public Goods}

Fundamental principles of Buchanan's "fiscal philosophy"—drawing heavily on the work of the Swedish economist Knut Wicksell (1896, 1958; on Buchanan and Wicksell, see Marciano 2020)—shape his analysis of clubs: individualized prices for public goods, willingness to pay, and unanimity. To Buchanan, taxes are or should be viewed as prices-"taxes or contributions paid are exchanged for services rendered by the political unit” (1948, 38). Individuals buy public goods and services from the state as they buy private goods and services. Then, the principle of voluntarism held that individuals would pay these prices-even

\footnotetext{
${ }^{1}$ The James M. Buchanan papers are referred to as BP below and in the reference list [C0246, Special Collections Research Center, George Mason University Libraries].

${ }^{2}$ Buchanan's (1965a) article was unrelated to Charles Tiebout's "A Pure Theory of Local Expenditures" (1956). Buchanan (1957a, 1961b; Buchanan and Goetz 1972) disagreed with Tiebout's emphasis on mobility and spatial competition as a means to deal with free riding in public finance (for more details, see Boettke and Marciano 2017).
} 
when it meant paying for the external costs their consumption creates-because they benefit from the goods and services they consume. Finally, the principle of unanimity held that the tax structure should be determined by asking all individuals how much they are ready to contribute.

Unanimity served two purposes. First, it sought a form of justice: in the words of Wicksell (1896, 114; 1958, 90), "if justice requires no more, it certainly requires no less. In the final analysis, unanimity and fully voluntary consent in the making of decisions provide the only certain and palpable guarantee against injustice in tax distribution." Unanimity was indeed "a guarantee against action designed to benefit or harm special classes unjustly" (Buchanan 1951, 176), a means to avoid the "tyranny of the majority" (Buchanan 1948, 11) and, beyond, to protect "the working and poorer" (Johnson 2010, 193). Second, as Buchanan $(1951,177)$ insisted, since "no one is worse off if some allocation of the required tax can be found which is acceptable to everyone," unanimity guaranteed that the "Paretian conditions for optimum welfare" (Buchanan 1951, 177) are satisfied without resorting to interpersonal comparisons of utility and without using a social welfare function.

These were the bases of Buchanan's welfare economics, the basis for his reaction to Samuelson's (1954) analysis of the optimal provision of public goods.

Samuelson (1954) famously established three conditions to be satisfied to reach a Pareto-optimal allocation of resources in an economy with private and pure public goods. First, there was the standard optimality condition for private goods. Second, a specific condition for public goods-the sum of the individual marginal rates of substitution between a public good and any private good should be equal to a unique marginal rate of transformation between those two goods. Third, a condition based on a social welfare function would determine how much each individual would pay-this condition encapsulated the "normative judgments concerning the relative ethical desirability of different configurations involving some individuals being on a higher level of indifference and some on a lower" (Samuelson 1954, 387). The second and third of Samuelson's conditions were the object of Buchanan's criticism.

Buchanan rejected social welfare functions because they meant that individuals would be coerced. A social welfare function rests on "ethical evaluations" or "value judgements" (Buchanan 1959, 133). It "is an explicit expression of a value criterion" (Buchanan 1959, 133). More precisely, the values embodied in the social welfare function are those of the observer who builds it—an economist, decision maker, or social welfare planner. Indeed, interpersonal comparisons of utility are unavoidable in building a social welfare function-a social welfare function necessarily "embod[ies] interpersonal norms" (Buchanan 1955a, 2) or "involv[es] interpersonal considerations" (Buchanan 1955a, 1). However, this social welfare function requires that preferences could be "read" by an external observer, who can then derive individuals' marginal rates of substitution between the public and a private good and aggregate them to determine the optimal amount of public good to produce. An external observer can only have access to individual preferences if it is assumed that the utility functions are revealed by previous behavior-if, as Buchanan wrote to 
Samuelson, it is assumed that "individual ordinal preferences can be derived only by revealed choices" (Buchanan to Samuelson, February 25, 1955, BP; emphasis in original).

To Buchanan, however, individual preferences cannot be presumed before a choice is made. Preferences do not exist outside and independently from the choice itself. Buchanan wrote $(1969,72)$ :

$[\mathrm{T}]$ here is simply no means of determining, even indirectly, the value that they [individuals] place on the utility loss that might be avoided. In the classic example, how much would the housewife whose laundry is fouled give to have the smoke removed from the air? Until and unless she is actually confronted with this choice, any estimate must remain almost wholly arbitrary.

If no one can "read" preferences from behaviors, then the marginal rates of substitution supposedly "read" from the behavior of individuals, such as those used in the social welfare functions, are actually being imposed by the external observer. As Buchanan had written $(1959,133)$ :

Individual preferences, insofar as they enter the construction (and they need not do so) must be those which appear to the observer rather than those revealed by the behavior of the individuals themselves. In other words, even if the value judgments expressed in the function say that individual preferences are to count, these preferences must be those presumed by the observer rather than those revealed in behavior.

The external observer can be mistaken or biased-by imposing a value judgement-in the distribution of the costs of the public good. To avoid these pitfalls, Buchanan claimed that one should base the prices for public goods on individual's willingness to pay. This leads to the second set of criticism he raised against Samuelson.

Buchanan (1955a, 3) found Samuelson's abandonment of individualized prices for public goods and the use of a "unique marginal rate of substitution in production" to be problematic. This meant that Samuelson had abandoned price discrimination- "the relative 'prices' of collective and private goods are made uniform for all individuals." Removing price discrimination for private goods was "a step toward Pareto optimality" (Buchanan 1955a, 3), since consumers can adjust their consumption to equalize their marginal rate of substitution between two private goods to the relative price of these goods. However, removing price discrimination was a step away from Pareto optimality when there are public goods, because individuals cannot adjust their consumption of public goods. Indeed, the marginal rate of substitution between public and private goods is given. Thus, an individual whose marginal rate of substitution differs from the unique relative price will not be in an optimal situation, and an allocation of resources reached under Samuelson conditions—-that is, based on this unique exchange ratio—could 
hardly be optimal. Those who made little or no use of the public good could end up paying the same as those who extensively consume it. One could even envisage that one or a few individuals might bear the entire cost of provision of the public good (Buchanan to Samuelson, March 4, 1955, BP). Indeed: "It is true the summation of individual exchange ratios must be equal to the 'social' exchange ratio. But this does not allow the individual differences to be neglected, since there are many possible ways of adding up" (Buchanan 1955a, 5).

In Buchanan's view, prices for public goods should be individualized to allow an adjustment that was impossible to achieve through quantities. This was why Buchanan added an individual condition to satisfy a guarantee of an optimal provision of public goods. Buchanan's individual condition was actually the usual optimality condition for private goods extended to public goods. This condition stated that the cost of acquiring the collective good differs from one individual to the other and should correspond to the amount each individual is willing to pay for the good to guarantee a Pareto allocation of resources. Put differently, for each individual, the relative price of a public good in terms of a private good should equal the marginal rate of substitution between those two goods. To guarantee an optimal allocation of resources with private and public goods, Buchanan (1955a, 4; emphasis in original) wrote, "each individual must equate the marginal rate of substitution in consumption between any collective good and one private good with the marginal rate of substitution between these two goods in production to him." Then, each individual would be certain to be on "his own utility frontier" (Buchanan to Samuelson, March 4, 1955, BP).

The individual condition-Buchanan admitted-would be "redundant" (Buchanan to Samuelson, February 25, 1955, BP) or "not needed in the Samuelson formulation" (Buchanan 1955a, 7). Thus, Samuelson's condition "provide[d] a pure theory of public finance in the Samuelson welfare economics" (2; emphasis in original) - that is, in a frame in which exists a social welfare function. Given such a function, no additional individual condition was needed to say how the costs of the provision of the public good should be distributed among individuals. Individual shares were given by, and incorporated in, the social welfare function. However, Buchanan's condition became necessary for those who like him were "not willing move beyond the 'narrow' or Paretian version of modern welfare economics" (Buchanan 1955a, 1). Buchanan's condition was an "alternative" to Samuelson's social welfare function. "This is all that it ever intended to be" (Buchanan to Samuelson, March 4, 1955, BP). It was the condition for an alternative welfare economics in which there was no social welfare function. Adding up the individual willingness to pay was necessary and sufficient to guarantee a Pareto optimal allocation of resources. All individuals would agree to pay what they were asked to pay, because this was what they wanted to pay"[t]he amounts actually paid are made equal to the amounts willingly paid" (Buchanan to Samuelson, February 25, 1955, BP). In other words, unanimous consent would be reached. In Buchanan's welfare economics, unanimity replaced a Samuelson-style social welfare function. 


\section{Individualized Prices, Collective Action, and Clubs}

Unanimity is not easy to reach, and Buchanan's condition was not easy to satisfy. The prices for public goods could be individualized only if individuals revealed their true preferences and willingness to pay for the good. This was also a further point of disagreement between Buchanan and most economists, starting with Samuelson and Richard Musgrave.

Musgrave believed that when faced with a collective action problem, individuals would not indicate any willingness to bear the implied costs. Instead, driven by their self-interest, they would free-ride. In the late 1930s, Musgrave (1939, 220; see also Musgrave 1959) spoke of "the absence of a general willingness to comply with the obligation to contribute." Fifteen years later, Samuelson (1954, 388-89) wrote in a similar spirit: "It is in the selfish interest of each person to give false signals, to pretend to have less interest in a given collective consumption activity than he really has." As a consequence, in the presence of public goods and externalities, the use of individualized prices and nongovernment or decentralized mechanisms was impossible. Such "a failure of market catallactics" included, as Samuelson (1954, 389) noted, "voting and signaling schemes-by which he meant "'Scandinavian consensus', Kant's 'categorical imperative,' other devices meaningful only under conditions of 'symmetry', etc."-that Samuelson found "utopian." From Samuelson's $(1955,356)$ view, government intervention was the only option to deal with externalities and public goods: "Myriad 'generalized external economy and diseconomy' situations ... provide obvious needs for government activity" (for similar views at the time, see among others Brownlee and Heller 1956; Margolis 1957; Musgrave 1939, 1959; Wiseman 1957).

For his part, while Buchanan readily admitted that markets fail to allocate resources efficiently in the presence of public goods (1954a, b), he also believed that such failures did not indicate a need for government intervention. For one thing, there were many problems that individuals could not solve privately but that did not warrant collective action- "[t] he mere presence of public or collective needs [should not be] confused with the necessity for satisfying them . . . . The existence of 'undeniable' need does nothing toward proving that action must be taken to meet it" (Buchanan 1957b, 175; see also 1959; Buchanan and Tullock 1962; Buchanan and Stubblebine 1962; Buchanan and Kafoglis 1963). Buchanan, Wicksellian in his confidence, was convinced that at least under certain conditions individuals would cooperate to solve these market failures. In contrast to Samuelson, Musgrave, and many others, Buchanan claimed that individuals do not always free ride in the presence of public goods. Government intervention was required only when the voluntary individual efforts at collective action failed.

In Buchanan's view, the key issue for addressing issues of public goods, externalities, and other market failures was not to identify "those goods and services that exhibit 'publicness'” (1965b, 11). Instead, the first step was to start from the collective solutions individuals willingly devised. As a corollary, the role of the economist was to understand the conditions under which individuals would voluntarily act 
collectively and cooperate to solve or prevent market failures without having to rely on government intervention. Economists must "concentrate their attention on a particular form of human activity and upon the various institutional arrangements that arise as a result of this form of activity" (Buchanan 1964a, 213-14). This was the point Buchanan made in his Nobel prize lecture (1987). This was the research program Buchanan outlined in "What Should Economists Do?" (1964a) and to which belonged "An Economic Theory of Clubs" (1965a; 1964b). The goal was here to explain how individuals devise "consumption ownership-membership arrangements" (Buchanan 1965a, 1), "cost and consumption sharing arrangement[s]" (Buchanan 1965a, 2), "membership or sharing arrangements" (Buchanan 1965a, 13) or, still in other words, "an organization of persons designed solely for the objective of utilizing a single communal community" (1964b).

\section{Clubs, Small Numbers, and Property Rights}

Buchanan developed his "theory of co-operative membership" (1965a, 1) over many articles and books_including, among others, "An Economic Theory of Clubs" (1965a), "Simple Majority Voting, Game Theory and Resource Use" (1961a) and "Ethical Rules, Expected Values, and Large Numbers" (1965b). Indeed, one major aspects of Buchanan's analysis related to the number of persons involved in the problem. More precisely, clubs exist when and because some individuals are willing to cooperate and to act collectively. Such a willingness, in turn, depends on the number of persons affected by the market failure and on the nature of the property rights involved.

To Buchanan, free riding and cooperation depended on whether or not individuals were in large or in small groups, because it depended on the probability each individual "assigns to the various patterns of behavior for 'others' than himself" (1965b, 5; 1968b, 85). The point was crucial because it had been neglected by economists (see also Buchanan 1978, 364-65). Numbers were crucial to mark a difference with the economists with whom Buchanan disagreed and to explain when clubs would exist. Thus, in large groups, Buchanan argued individuals follow their self-interest in the narrow sense of the word independently from how others behave. Each individual treats others as parts of the environment, assuming that their action cannot influence others' and hence not adapting their behaviors to what others do in a way that would allow collective action to emerge (Buchanan 1965b, 1968a). They face what Buchanan called "the large-number dilemma" (1965b, 1968b). Although individuals are aware that they would be better off by contributing to the provision of the public good or internalizing the external effects of their action, they nonetheless "refuse, rationally, to contribute to this cost on an individualistic and voluntary basis” (1965b, 9). In short, they behave as assumed by

\footnotetext{
${ }^{3}$ The concept of club goods was not totally new to Buchanan. For predecessors, see Wicksell (1896, 114; 1958, 90), Benham (1934, 451), and Wiseman (1957).
} 
the standard Samuelson/Musgrave public finance doctrine. Collective action fails. A certain form of state intervention was inevitable.

The situation was radically different in small groups. In those environments, Buchanan argued individuals behave strategically, adapting their behavior to what others do and what they anticipate about the behavior of others. In a small group, individuals might in some cases behave morally and follow a Kantian rule of actionto act in accordance with the rules you would like to see followed by everyone (Buchanan 1961a, 1965b, 1968b). If individuals in this setting follow an ethical rule of action, they contribute to the provision of public goods, internalize the effects they have on others-say, in trying not to make too much noise in public spaces-or bargain with others over these external effects or, in addition, do not cheat on their commitments. To put it differently, they act collectively. To Buchanan, there was no doubt that in small groups, the probability to follow this Kantian principle was higher than in large groups (see also 1978, 365).

The willingness to cooperate in smaller groups, as likely as it was, was not guaranteed without certain rules. Individuals could indeed behave opportunistically, "find [ing] it to [their] advantage to conceal [their] true preferences and to give false signals about those preferences to [their] opponents-partners" (Buchanan $1968 \mathrm{~b}, 81$ ). Such behaviors could be tolerated only up to a certain point (Buchanan 1968a, 357-58). The danger that some individuals could free ride was an obstacle to collective action. Individuals would indeed "be reluctant to enter voluntarily into cost-sharing arrangements ... [i]f they think that exclusion will not be fully possible, that they can expect to secure benefits as free riders without really becoming fullfledged contributing members of the club" (Buchanan 1965a, pp. 13-14). Free riders should be excluded from the group.

Exclusion-that is, the exclusion of those who do not pay the membership fees-therefore has to be possible. In small groups, where relationships were personal, "the possibility of excluding genuine non-conformists will normally be present” (Buchanan 1968b, 87). But it was much more efficient if property rights were used to guarantee the exclusion of free riders, to prevent free-riding behaviors, and therefore to secure the benefits of inclusion in the club to its members (Buchanan 1965a, 13; see also Buchanan and Tullock 1962, 44). Property rights were necessary to allow the exclusion of potential free riders.

A club was therefore viewed as an institutional arrangement devised to include the individuals who were willing to cooperate-that is ready to adopt an ethical rule of behavior-and to exclude those who could be tempted to free ride. As Buchanan (1965a, 13) wrote, a "theory of club is . . . a theory of optimal exclusion, as well as one of inclusion." As a mechanism, clubs could be used to deal with many instances of market failures. Local goods-a swimming pool, which was the example Buchanan took in his 1965 article or a highway network as in the preliminary 1964 versioncome immediately to mind. Thus, clubs seem to be rather small groups. However, there was no conceptual reason why clubs could not exist to deal with less impure and less local public goods, and even with pure public goods in the standard Samuelsonian sense of the word-such as defense. Buchanan cited lighthouses or a vaccine 
as examples of goods that could be dealt with through clubs, provided that property rights were defined to prohibit free riders from benefiting of the good. Potentially, to Buchanan (1965a, 13), there was no limit to physical excludability: "Physical exclusion is possible, given sufficient flexibility in property law, in almost all imaginable cases, including those in which the interdependence lies in the act of consuming itself."

\section{Clubs, Individualized Prices, and Pareto Optimality}

Once ethical and legal rules guaranteed that individuals would cooperate and pay the price to support the club, the next question obviously bore on how the costs of the public good would be shared among members. For Buchanan, what would be a club pricing mechanism? He answered the question in "An Economic Theory of Clubs" (1965b) and also in incomplete drafts available in the Buchanan Papers, which we treat here as a single manuscript (1964b).

Initially, Buchanan envisaged a system in which consumers were charged a twopart price. First, a charge per unit of consumption set at the level of the marginal cost. Second, a flat or fixed fee to cover the costs of the provision of the good or the difference between the marginal and average cost, given that public goods and club goods are frequently decreasing cost industries. Inspired, again, by Wicksell and his defense of the use of marginal cost pricing for decreasing cost public enterprises, Buchanan suggested to price highway services by using such a two-part tariff (1952, 1955b). ${ }^{4}$ It would consist of a gasoline tax-the "rough equivalent to a mileage toll" (Buchanan 1952, 102) —and motor vehicle license fees-to include elements such as vehicle weight, the type of road used, and the time at which vehicle travels. Buchanan added, without giving any details, that "tax financing [should] be considered ... to cover the total costs of construction and maintenance" (Buchanan 1952, 100). 5

Defined in this way, the prices for highway services would vary from one individual to the other, which made sense for Buchanan since the benefits received by each individual were different. Another reason was that the costs each motorist generated, and that had to be covered by the price, were different. There were the costs of highway depreciation that depended on the type of vehicle used and, most importantly, the costs imposed on others. Indeed, Buchanan pointed out

\footnotetext{
${ }^{4}$ Wicksell argued that public enterprises should "charg[e] fees equal to the marginal costs of providing the service and making up the deficit by tax revenues" (Buchanan 1951, 174). The tax was raised to finance the deficit caused by the difference between the average and marginal cost that characterized such industries. They should be paid by the users of the public good, that is, by "the individuals who benefit from the proposed enterprise" (176; see also Buchanan 1948, 1949, 1952, 108). Other prominent economists of the time like Lerner (1944) and Hotelling (1938) argued that such taxes should be levied on all taxpayers-including nonusers-in a non-discriminatory way.

${ }^{5}$ In his early writing, Buchanan $(1952,102)$ ruled out highway tolls. The system would have to be "comprehensive and highly differentiated," and it would be "completely unworkable from an administrative point of view, and would be uneconomic besides."
} 
using highways generated "spillover" effects. Thus, the user charge had to be set at the level of the marginal social cost. Users would also have to pay the "spillover" costs" resulting from "[t]he progressive deterioration in quality of highway service as congestion increases" and that were "represented in poorer service provided [sic] all users" $(1952,100)$. Thus, for instance, "The motorist who drives a new and efficient vehicle does "benefit" more from highways than does the motorist who drives the "Model A." But the latter should pay a higher price because he adds more to social cost" (Buchanan 1952, 106).

Price discrimination would ensure that only those willing to pay would actually demand road services. Others would exclude themselves from the use of roads and highways. User prices would efficiently restrict demand, which was necessary to solve the major problem of that congestion on highways. To Buchanan, congestion evidenced too high a demand for highway services. The key was to ration demand: "The answer to the whole highway problem lies in 'pricing' the highway correctly. The existence of congestion on our streets and highways is solely due to the fact that we do not charge high enough 'prices' for their use" (1955b, 14-15).

But eventually, Buchanan changed his mind and rejected the two-part tariffwhich is quite ironical if one remembers that such tariff is commonly linked to a club pricing mechanism (Sandler and Tschirhart 1980, 1504). Instead, Buchanan's preferred club pricing should not include a charge per unit, a variable part. Buchanan even suggested that it was more useful to stop talking of prices and to refer to "shares" (1965a, 12): "Users pay a share in the common costs of providing the facility" (1964b). However, those shares were not the same for all consumers. Buchanan (1965a, 4) noted that, "[f] or simplicity, we may assume equal sharing" but immediately added that "this is not necessary for the analysis." Buchanan stuck to individualized prices. In clubs, price discrimination is possible (see also Wiseman $1957,64)$. The price, or shares, paid in the club should differ from one individual to the other. The difference should reflect, first, the spillover costs that using a public good generates and, second, the willingness to pay for the good. These two principles remained important.

Buchanan also changed his mind about how to take congestion into account in clubs. Club members-motorists, for instance-should no longer be asked to pay for the spillover costs and club goods should no longer be priced on the marginal social cost: [t] he club approach . . . involves no attempt to impose a charge on users that reflects spillover congestion costs. (Buchanan 1964b). ${ }^{6}$ The reason seemed to have been that the externalities generated by highway users were nonseparable and, as Otto Davis and Andrew Whinston had demonstrated, marginal cost pricing could be used only when technological externalities are separable (Davis and Whinston

\footnotetext{
${ }^{6} \mathrm{He}$ had "come to the view that all the stuff on trying to "price' highways by measuring marginal costs of congestion, a position that [he] firmly supported in past, is conceptually wrong because it is impossible." (Buchanan to Tolley, October 7, 1964, BP)
} 
1962, 247).7 If the spillover costs could thus no longer be included from the cost side, they should be taken into account from the benefit side. ${ }^{8}$ They were no longer paid by those who create the spillover effects but by those who suffer from them-if they are willing to do so-as foregone benefits. Buchanan (1964b) now claimed: "The costs of congestion enter the analysis through their effects on the estimated benefits to be received by final consumers." Each club member is characterized by a certain willingness to pay for additional members-a "rate (which may be negative) at which the individual is willing to give up (accept) money in exchange for additional members in the sharing group" (Buchanan 1965a, 4). Each additional member generates costs once in the club. Thus, "when the marginal benefits that he secures from having an additional member ... are just equal to the marginal costs that he incurs from adding a member . . . an individual attains full equilibrium in club size" (1965a, 5).

Pareto optimality requires that each share was based on the individual's willingness to pay for having additional members in the club as well as the willingness to pay for the good produced by the club. That was the second element that club pricing should include. Buchanan (1965a, 5) thus added another principle stating that, for each individual, the "marginal rate of substitution between goods $X_{j}$ [the club good] and $X_{r}$ [the numeraire good], in consumption, must be equal to the marginal rate of substitution between these same two goods in 'production' or exchange." This was exactly the condition he had used in his 1955 comment to Samuelson. It reflected his conviction that each individual should pay the price that the individual is willing to pay. Clubs were thus meant to implement this so-important condition. This was also clearly a reason for which club shares would be individualized and different from one individual to the other. Again, Buchanan was implying that his condition and only his could guarantee a Pareto-optimal allocation of resources.

Thus, Buchanan's clubs were a means to implement the prices individuals were ready to pay. The two dimensions-foregone benefits and effective benefits-guarantee that outcome. Complementarily, what Buchanan meant was that, without clubs for public goods, individuals would pay a price that does not satisfy their preferences. Clubs were a means to avoid coercion.

\section{Conclusion}

With “An Economic Theory of Clubs," Buchanan (1965a) was trying to do much more than just fill in the conceptual gap between the extremes of pure public goods and pure private goods. He was not even trying to define a category of goods.

\footnotetext{
${ }^{7}$ An externality is separable if the consumption or output of $i$ does not affect the marginal utility or cost of $j$. Otherwise, it is non-separable.

8 “ $[\mathrm{T}]$ he use of price to restrict usage to some 'optimal' level of traffic remains relevant [but], we should, I now think, come at price differently, and not via the cost side at all” (Buchanan to Tolley, October 7, 1964).
} 
He sought to develop a different form of welfare economics, in which there is no social welfare function and in which utility functions cannot be "read" by external observers, but where individual preferences can instead only be revealed by actions taken in response to prices. Buchanan adopted this perspective to analyze the pricing of public goods and to discuss clubs. Buchanan explicitly presents his clubs as a means to replace Samuelson's condition for optimal spending on public goods (1965a, 6). Indeed, Buchanan's clubs are foreign and incompatible with the role that club goods play in traditional Samuelson-style public economics.

I am grateful to Peter J. Boettke, David Coker, Andrew Farrant, Jean-Baptiste Fleury, and the editors of the Journal for very thoughtful comments.

\section{References}

Benham, Frederic C. 1934. "Notes on the Pure Theory of Public Finance." Economica 1(4): 436-58.

Boettke, Peter J., and Alain Marciano. 2017. "The Distance between Buchanan's 'An Economic Theory of Clubs' and Tiebout's 'A Pure Theory of Local Public Expenditures.' New Insights Based on an Unpublished Manuscript.” European Journal of the History of Economic Thought 24 (2): 205-37.

Brownlee, Oscar H., and Walter W. Heller. 1956. "Highway Development and Financing." American Economic Review 46 (2): 232-50.

Buchanan, James M. 1948. Fiscal Equity in a Federal State. Chicago: University of Chicago.

Buchanan, James M. 1949. "The Pure Theory of Government Finance: A Suggested Approach.” Journal of Political Economy 57 (6): 496-505.

Buchanan, James M. 1951. "Knut Wicksell on Marginal Cost Pricing." Southern Economic Journal 18 (2): -173-78.

Buchanan, James M. 1952. “The Pricing of Highway Services.” National Tax Journal 5 (2): 97-106.

Buchanan, James M. 1954a. "Resource Allocation and the Highway System.” Unpublished, BP.

Buchanan, James M. 1954b. "Consumption Interdependence and the Interpretation of Social Cost." Unpublished, BP.

Buchanan, James M. 1955a. "A Note of the Pure Theory of Public Expenditure." Unpublsihed, BP, reprinted in P. J. Boettke and A. Marciano, 2020, The Soul of Classical Political Economy: James M. Buchanan from the Archives, Mercatus Center.

Buchanan, James M. 1955b. Traffic, Tolls and Taxes. The Economics of the Nation's Highway Problem. Unpublished, BP.

Buchanan, James M. 1957a. "The Pure Theory of Local Expenditure: Comment.” Unpublished, BP.

Buchanan, James M. 1957b. "Federal Expenditure and State Functions." In Federal Expenditure Policy for Economic Growth and Stability, 174-79. Washington, DC: United States Government Printing Office.

Buchanan, James M. 1959. "Positive Economics, Welfare Economics, and Political Economy." Journal of Law and Economics 2: 124-38.

Buchanan, James M. 1961a. "Simple Majority Voting, Game Theory and Resource Use." Canadian Journal of Economics and Political Science 27 (3): 337-48.

Buchanan, James M. 1961b. "Comments." In Public Finances: Needs, Sources, and Utilization, edited by James Buchanan, 122-29. Princeton: Princeton University Press.

Buchanan, James M. 1964a. "What Should Economists Do?” Southern Economic Journal 30 (3): $213-22$.

Buchanan, James M. 1964b. "The "Club" Approach to Highways." mimeo, BP.

Buchanan, James M. 1965a. "An Economic Theory of Clubs.” Economica 32 (125): 1-14.

Buchanan, James M. 1965b. "Ethical Rules, Expected Values, and Large Numbers.” Ethics 76 (1): 1-13.

Buchanan, James M. 1968a. “A Behavioral Theory of Pollution.” Economic Inquiry 6 (5): 347-58.

Buchanan, James M. 1968b. The Demand and Supply of Public Goods. Indianapolis: Liberty Fund, 1999.

Buchanan, James M. 1969. Cost and Choice. An Inquiry in Economic Theory. Chicago: Markham Publishing. Co. 
Buchanan, James M. 1978. "Markets, States, and the Extent of Morals.” American Economic Review 68 (2): 364-68.

Buchanan, James M. 1987. "The Constitution of Economic Policy.” American Economic Review 77 (3): 243-50.

Buchanan, James M. 2007. Economics from the Outside In: "Better Than Plowing" and Beyond. Texas A\&M University Press.

Buchanan, James M., and Charles J. Goetz. 1972. "Efficiency Limits of Fiscal Mobility: An Assessment of the Tiebout Model." Journal of Public Economics 1 (1): 25-43.

Buchanan, James M., and Milton Z. Kafoglis. 1963. "A Note on Public Goods Supply." American Economic Review 53 (3): 403-14.

Buchanan, James M., and William C. Stubblebine. 1962. "Externality." Economica 29 (116): 371-84.

Buchanan, James M., and Gordon Tullock. 1962. The Calculus of Consent: Logical Foundations of Constitutional Democracy. Ann Arbor: University of Michigan Press.

Davis, Otto A., and Andrew Whinston. 1962. "Externalities, Welfare, and the Theory of Games." Journal of Political Economy 70 (3): 241-62.

Hotelling, Harold. 1938. "The General Welfare in Relation to Problems of Taxation and of Railway and Utility Rates.” Econometrica 6 (3): 242-69.

Johnson, Marianne. 2010. "Wicksell's Social Philosophy and His Unanimity Rule." Review of Social Economy 68 (2): 187-204.

Lerner, Abba P. 1944. The Economics of Control: Principles of Welfare Economics. New York: Macmillan.

Marciano, Alain. 2020. "How Wicksell became important for Buchanan: a historical account of a (relatively) slow epiphany.” Journal of Public Finance and Public Choice, 35 (2): 181-203.

Margolis, Julius. 1957. "Welfare Criteria, Pricing, And Decentralization of a Public Service." Quarterly Journal of Economics 71 (3): 448-63.

Musgrave, Richard Abel. 1939. "The Voluntary Exchange Theory of Public Economy." Quarterly Journal of Economics 53 (2): 213-37.

Musgrave, Richard A. 1959. The Theory of Public Finance. New York: McGraw Hill Book Co.

Samuelson, Paul A. 1954. "The Pure Theory of Public Expenditure." Review of Economics and Statistics 36 (4): 387-89.

Samuelson, Paul A. 1955. "Diagrammatic Exposition of a Theory of Public Expenditure." Review of Economics and Statistics 37: 350-56.

Sandler, Todd. 2013. "Buchanan clubs." Constitutional Political Economy 24 (4): 265-84

Sandler, Todd, and John T. Tschirhart. 1980. "The Economic Theory of Clubs: An Evaluative Survey." Journal of Economic Literature 18 (4): 1481-1521.

Sandler, Todd, and John T. Tschirhart. 1997. "Club theory: Thirty Years Later." Public Choice 93: 335-55.

Tiebout, Charles. M. 1956. "A Pure Theory of Local Expenditures.” Journal of Political Economy 64 (5): 416-24.

Wicksell, Knut. 1896. Finanztheoretische Untersuchungen. Jena: Gustav Fischer.

Wicksell, Knut. 1958. “A New Principle of Just Taxation.” (1896 J. M. Buchanan, Trans.). In Classics in the Theory of Public Finance, edited by R. Musgrave and A. Peacock, 72-118. New York: St. Martin's Press.

Wiseman, Jack. 1957. "The Theory of Public Utility Price-An Empty Box.” Oxford Economic Papers 9 (1): 56-74. 
